\title{
Metal complexes of Schiff bases derived from 2-thiophenecarboxaldehyde and mono/diamine as the antibacterial agents
}

\author{
Mohammad Nasir Uddin ${ }^{1, ~ *, ~ D i d a r u l ~ A l a m ~ C h o w d h u r y ~}{ }^{1}$, Md. Moniruzzman Rony ${ }^{1}$, \\ Md. Ershad Halim ${ }^{2}$ \\ ${ }^{1}$ Department of Chemistry, University of Chittagong, Chittagong-4331, Bangladesh \\ ${ }^{2}$ Department of Chemistry, University of Dhaka, Dhaka, Bangladesh
}

\section{Email address:}

nasircu72@gmail.com (M. N. Uddin)

\section{To cite this article:}

Mohammad Nasir Uddin, Didarul Alam Chowdhury, Md. Moniruzzman Rony, Md. Ershad Halim. Metal Complexes of Schiff Bases Derived from 2-Thiophenecarboxaldehyde and Mono/Diamine as the Antibacterial Agents. Modern Chemistry.

Vol. 2, No. 2, 2014, pp. 6-13. doi: 10.11648/j.mc.20140202.11

\begin{abstract}
The Schiff bases, formed by condensation of 2-thiophenecarboxaldehyde with 2-aminothiophenol (Lㅌ) and propane-1,2-diamine $\left(\mathrm{L}_{1}\right)$, and their complexes of $\mathrm{Ni}(\mathrm{II}), \mathrm{Cu}(\mathrm{II}), \mathrm{Zn}(\mathrm{II})$ and $\mathrm{Cd}(\mathrm{II})$ have been prepared and characterized by elemental analysis, and magnetic and spectroscopic measurements. Infrared and NMR spectra of the complexes agree with the coordination to the central metal atom through the nitrogen of the azomethine $(-\mathrm{HC}=\mathrm{N}-)$ group and the sulfur atom of the thiophene ring. Magnetic susceptibility data coupled with electronic suggest octahedral structure for the complexes. Conductance measurements suggest the non-electrolytic nature of the complexes. Stoichiometry of complexes has been suggested as $\left[\mathrm{M}(\mathrm{L})_{2}\right]$ and $\left[\mathrm{ML}_{1} \mathrm{Cl}_{2}\right]$. The Schiff base and its metal chelates have been screened for their in vitro antibacterial activity against four human pathogenic bacteria. Ligands show moderately whereas some of metal chelates show highly antibacterial activity against them.
\end{abstract}

Keywords: Metal Complexes, Schiff Bases, 2-Thiophenecarboxaldehyde, 2-Aminothiophenol, Propane-1, 2-Diamine, Antibacterial Activity

\section{Introduction}

Schiff base ligands can be synthesized from an amine and a carbonyl compound by nucleophilic addition forming a hemi-aminal group followed by dehydration to generate an imine compound [1]. Schiff bases, an important class of ligands plays an important role in the development of coordination chemistry as they can easily form stable complexes with most of the transition metals [2]. Metal chelates of the Schiff bases derived from salicylaldehyde and amino acids have been shown to be important class of compounds in elucidating the mechanism of transamination reaction in biological systems [3]. Metal complexes of the Schiff bases possess numerous applications including antibacterial, antifungal and other biological applications, as well as clinical, analytical and industrial in addition to their important roles in catalysis [4].

A large number of Schiff base complexes of various transition metal ions with a variety of donor atoms have been reported. Synthesis, spectroscopic and electrochemical properties of some complexes of a new symmetric bidentate Schiff base ligand of bis ((3(2-nitrophenyl) allylidene) propane-1,2-diamine (L) with a general formula of $\mathrm{MLX}_{2}(\mathrm{M}=\mathrm{Cd}(\mathrm{II})$ and $\mathrm{Hg}(\mathrm{II}) ; \mathrm{X}=\mathrm{Cl}$-, $\mathrm{Br}-, \mathrm{I}-, \mathrm{SCN}-$ and $\mathrm{NO}_{3}-$ ) are reported [5]. Several new dioxouranium(VI) complexes of Schiff bases, derived from salicylaldehyde, substituted salicylaldehydes, 2-hydroxy-1naphthaldehyde and 2-aminothiophenol, have been prepared and characterized on the basis of their elemental analyses, IR and electronic absorption spectra and magnetic susceptibility measurements. The results suggest that each Schiff base is a bivalent anion with tridentate ONS donors from the phenolic oxygen, azomethine nitrogen and thiophenolic sulfur [6]. Some dioxouranium (VI) bis-complexes of ligands (LH); benzoylhydrazine (BH), salicyloylhydrazine $(\mathrm{SalH})$, nicotinoylhydrazine $(\mathrm{NH})$ and 
their Schiff bases with acetone; isopropylenebenzoylhydrazine (IPBH), isopropylenesalicyloylhydrazine (IPSalH), isopropylene-nicotinoylhydrazine (IPNH) in their both keto and enol forms have been prepared [7].

Most of the tetradentate Schiff base ligands are formed by the condensation of $\beta$-diketones or o-hydroxyaldehydes or ketones with diamines. These ligands with ONNO donor atom set are well known to coordinate with various metal ions and this has attracted the interest of many authors [8]. The titanium(IV) complexes of the unsymmetrical Schiff base ligands of ethylenediamine and salicylaldehyde, o-hydroxyacetophenone, o-hydroxynapthaldehyde have been prepared and characterized when unsymmetrical ligands are synthesized through in situ partial displacement of the symmetrical bis-Schiff bases [9].

Metal complexes [Fe(II), Co(II), Ni(II), Cu(II), Zn(II), or $\mathrm{Cd}(\mathrm{II})]$ of the Schiff bases formed by condensation of 2-thiophenecarboxaldehyde with 2-aminopyridine, $\mathrm{N}$-(2-thienylmethylidene)-2-aminopyridine have been prepared and characterized [10]. $\mathrm{Co}(\mathrm{II}), \mathrm{Ni}(\mathrm{II})$ and $\mathrm{Cu}(\mathrm{II})$ complexes of three Schiff bases, derived from the condensation reaction of thiophene-2-carbaldehyde and DL-alanine, DL-valine and DL-phenylalanine, have been synthesized and characterized by their analytical and spectral data [3]. (TCPA 4) Copper (II) and Iron (III) complexes of Schiff base ligand namely (Z)-3-hydroxy-4-((5-methylthiophen-2-yl) methyleneamino) benzoic acid derived from the condensation of 5-methyl-2-thiophene carboxaldehyde with 4-amino-3-hydroxy benzoic acid were synthesized [4]. $\mathrm{Mg}(\mathrm{II}), \mathrm{Ca}(\mathrm{II})$ and $\mathrm{Ba}(\mathrm{II})$ metal chelates of the Schiff base moiety, formed from condensation of 2-thiophenecarboxaldehyde with 2-chlorophenyl hydrazine, have been prepared and characterized by elemental analysis and infrared and ${ }^{1} \mathrm{H}-\mathrm{NMR}$ spectroscopic measurements [11]. CoII, NiII and CuII complexes of Schiff bases formed by condensation of 2-thiophenecarboxaldehyde and propylamine, $\mathrm{N}$-[2-thienylmethylidene]-1-propanamine, or ethylamine, $\mathrm{N}$-[2- thienylmethylidene] ethanamine, have been prepared and characterized [12]. The present work has been an attempt to study preparation, characterization and antibacterial activities some metal complexes using new tridentate and tetradentate Schiff base ligand having thiophenecarboxaldehyde moiety.

\section{Experimental}

\subsection{Chemicals}

2-aminothiophenol, 1,2-propane-di-amine, 2-thiophenecarboxaldehyde were obtained from M/S. E. Merk (Germany). Methanol, chloroform, N, N-dimethyl formamide (DMF), dimethylsulphoxide (DMSO) and carbon-tetrachloride were obtained from Aldrich Chemical Company Ltd. Ethyl alcohol was obtained from Carew and company Ltd. Perchloric acid, nitric acid, sulphuric acid and disodiam salt of ethylenediaminetetraacitic acid were obtained from BDH Chemicals Ltd. All chemicals except solvent were used as received. Solvents were dried by standard methods and distilled under an inert atmosphere.

\subsection{Preparation of Schiff Base Ligands}

\subsubsection{2-Thiophenecarboxaldehyde-2-Aminothiophenol, TPCA-ATPH (LH)}

2-aminothiophenol contains one $-\mathrm{NH}_{2}$ group attached to the aromatic ring with a sulfhydryl group (-SH) in 2 position. An active carbonyl group reacts with $-\mathrm{NH}_{2}$ group of 2-Aminothiophenol yielding a Schiff base product containing azomethine $(>\mathrm{C}=\mathrm{N}-)$ function. A hot solution $\left(60{ }^{\circ} \mathrm{C}\right)$ of 2 -aminothiophenol $(10 \mathrm{mmol})$ in $25 \mathrm{~mL}$ of ethanol was mixed with a hot solution $(60 \circ \mathrm{C})$ of 2-thiophenecarboxaldehyde $(10 \mathrm{mmol})$ in the same solvent and the reaction mixture was left under reflux for one hr. The solid product formed was separated by filtration, purified by crystallization from ethanol and washed with diethyl ether and then dried in a vacuum desiccator over anhydrous calcium chloride.

\subsubsection{2-Thiophenecarboxaldehyde-1, 2-Propanediamine, \\ TPCA-Pn-TPCA $\left(L_{l}\right)$}

1,2-propanediamine contains two amino $\left(-\mathrm{NH}_{2}\right)$ groups attached with propane group at 1,2- positions. An active carbonyl group reacts with $-\mathrm{NH}_{2}$ group of 1 , 2-propanediamine yielding a Schiff base product containing azomethine $(>\mathrm{C}=\mathrm{N}-$ ) function. 2-thiophenecarboxaldehyde (30 mmol) was dissolved in $60 \mathrm{~mL}$ of ethanol and 1,2-propanediamine (15 mmol) was added drop wise to this solution with continuous stirring. The solution was refluxed for about one hour. Then it was cooled, allowed to stand in a deep freeze for cooling over some days (3-4). Brown product was formed after cooling. The product was then filtered off, washed with ethanol and dried in a desiccator anhydrous calcium chloride.

The color, yield and melting point of the prepared ligands are given in Table 1.

\subsection{Synthesis of Metal Complexes}

The metal complexes of the Schiff bases, $\mathrm{L} \underline{\mathrm{H}}$ and $\mathrm{L}_{1}$, were prepared by the addition of a hot solution $\left(60^{\circ} \mathrm{C}\right)$ of the appropriate metal chloride, nitrate, or acetate $(1 \mathrm{mmol})$ in an ethanol-water mixture $(1: 1,25 \mathrm{~mL})$ to the hot solution $\left(60^{\circ} \mathrm{C}\right)$ of the Schiff bases $\left(2 \mathrm{mmol} \mathrm{LH}\right.$ and $\left.1 \mathrm{mmol} \mathrm{L}_{1}\right)$ in the same solvent $(25 \mathrm{~mL})$. The resulting mixture was stirred under reflux for $1 \mathrm{~h}$ whereupon the complexes precipitated. They were collected by filtration, washed with a 1:1 ethanol-water mixture and diethyl ether. The color, Yield, melting point and \% of element content and elemental analysis of the prepared complexes are given in Table 1. 
Table 1. Color, \% of Yield, M. P. and \% of Metal contents of the prepared Schiff bases and their metal complexes

\begin{tabular}{|c|c|c|c|c|c|c|c|}
\hline \multirow[b]{2}{*}{ Complexes } & \multirow[b]{2}{*}{ Color } & \multirow[b]{2}{*}{ Yield (\%) } & \multirow{2}{*}{$\begin{array}{l}\text { M.P. } \\
\left({ }^{\circ} \mathrm{C}\right)\end{array}$} & \multirow{2}{*}{$\begin{array}{c}\text { \% of Metal } \\
\text { (Calc.) }\end{array}$} & \multicolumn{3}{|c|}{ Elemental analysis } \\
\hline & & & & & $\% \mathrm{C}$ & $\% \mathrm{H}$ & $\% \mathbf{N}$ \\
\hline TPCA-ATP & Yellow & 80 & 180 & - & $59.97(60.27)$ & $4.32(4.11)$ & $6.19(6.39)$ \\
\hline$\left[\mathrm{Ni}(\mathrm{TPCA}-\mathrm{ATP})_{2}\right]$ & Red & 88 & $>250$ & $\begin{array}{l}14.79 \\
(15.5)\end{array}$ & $\begin{array}{c}50.07 \\
(49.72)\end{array}$ & $\begin{array}{c}3.55 \\
(3.77)\end{array}$ & $\begin{array}{c}5.55 \\
(5.27)\end{array}$ \\
\hline$\left[\mathrm{Cu}(\mathrm{TPCA}-\mathrm{ATP})_{2}\right]$ & Black & 86 & $>250$ & $\begin{array}{l}12.63 \\
(11.5)\end{array}$ & $\begin{array}{c}52.09 \\
(52.85)\end{array}$ & $\begin{array}{l}3.01 \\
(3.2)\end{array}$ & $\begin{array}{c}5.35 \\
(5.61)\end{array}$ \\
\hline$\left[\mathrm{Zn}(\mathrm{TPCA}-\mathrm{ATP})_{2}\right]$ & Brown & 80 & $>300$ & $\begin{array}{c}25.7 \\
(25.55)\end{array}$ & $\begin{array}{c}52.21 \\
(52.69)\end{array}$ & $\begin{array}{c}3.58 \\
(3.19)\end{array}$ & $\begin{array}{c}5.53 \\
(5.59)\end{array}$ \\
\hline$\left[\mathrm{Cd}(\mathrm{TPCA}-\mathrm{ATP})_{2}\right]$ & Yellow Brown & 87 & $>250$ & $\begin{array}{c}20.37 \\
(20.92)\end{array}$ & & & \\
\hline TPCA-pn-TPCA & brown & 85 & 160 & - & & & \\
\hline [Ni(TPCA-pn-TPCA)Cl $\left.{ }_{2}\right]$ & Brown & 85 & $>300$ & $\begin{array}{c}14.91 \\
(13.75)\end{array}$ & $\begin{array}{c}39.63 \\
(38.25)\end{array}$ & $\begin{array}{c}4.06 \\
(4.28)\end{array}$ & $\begin{array}{c}7.11 \\
(6.58)\end{array}$ \\
\hline [Cu(TPCA-pn-TPCA) $\left.\mathrm{Cl}_{2}\right]$ & Brown & 85 & $>300$ & $\begin{array}{c}15.93 \\
(14.85)\end{array}$ & $\begin{array}{c}39.14 \\
(40.81)\end{array}$ & $\begin{array}{c}4.02 \\
(4.25)\end{array}$ & $\begin{array}{c}7.03 \\
(5.95)\end{array}$ \\
\hline [Zn(TPCA-pn-TPCA) $\left.\mathrm{Cl}_{2}\right]$ & Light Brown & 85 & $>250$ & $\begin{array}{c}16.31 \\
(17.01)\end{array}$ & & & \\
\hline [Cd(TPCA-pn-TPCA) $\left.\mathrm{Cl}_{2}\right]$ & Brown & 88 & $>250$ & $\begin{array}{c}25.13 \\
(25.51)\end{array}$ & $\begin{array}{c}34.87 \\
(33.95)\end{array}$ & $\begin{array}{c}3.58 \\
(3.18)\end{array}$ & $\begin{array}{c}6.26 \\
(5.99)\end{array}$ \\
\hline
\end{tabular}

\subsection{Test for Antibacterial Evaluation}

Synthesized complexes were screened by the agar well diffusion method for their antibacterial activity against different types of bacteria, gram positive- Bacillus cereus and gram negative- Salmonella typhi, pseudomonas alruginosa, Escherichia coli regarded as pathogen to man. All media and bacteria suspension were prepared using a suitable method. The in-vitro evaluation of antimicrobial activities was performed according to the diffusion technique [13]. The bacteria were grown in nutrient broth at $37^{\circ} \mathrm{C}$ for 24 hours. The complexes were tested using diffusion on solid media. Sterile $(5 \mathrm{~mm})$ diameter sensitivity paper disc were impregnated with concentration of dimethylformamide (DMF) and their bimetallic complexes at concentration of $50 \mu \mathrm{g} \mathrm{cm}^{-3}$ and placed in the nutrient agar. The plates were then incubated for 24 hours. The results were recorded by measuring the growth inhibition (\% zones of inhibition) surrounding the disc.

\subsection{Analytical Methods}

The analyses of the metal contents of the prepared complexes were obtained by Atomic Absorption Spectrophotometer (model Thermo Scientific ICE-3000) from B.C.S.I.R. Laboratory, Chittagong, Bangladesh. The Infrared spectra of the prepared ligands and complexes were obtained by FTIR spectrophotometer (Model-883, Perkin-Elmer) using $\mathrm{KBr}$ as the matrix in the range $400-4000 \mathrm{~cm}^{-1}$ from research laboratory of Department of Chemistry, University of Chittagong. Electronic absorption spectra were run on Shimadzu UV-Visible Recording Spectrophotometer (Model-1800) using $1 \mathrm{~cm}$ cell in the research laboratory of the Department of Chemistry, University of Chittagong. An electrothermal melting point apparatus was used for the determination of the melting or decomposition points of the complexes and the ligands. Using $\mathrm{N}, \mathrm{N}$-dimethylformamide (DMF) as the solvent the solutions of the complexes (of the order of $10^{-3} \mathrm{M}$ ) were used for conductivity measurements. Conductivity measurement was performed on a Philips Conductivity Meter (Model-HI 9255). Determination of conductivity of an electrolytic solution involves measuring of the electrical resistance of that solution at a particular temperature, usually $25^{\circ} \mathrm{C}$. Magnetic susceptibility values of some of the prepared complexes were determined using the Magnetic Susceptibility Balance in the research laboratory of the Department of Chemistry, University of Chittagong. Elemental analysis data and mass spectra were obtained from Shiumyozu's Laboratory, Department of Applied Chemistry at Kyushu University, Japan, by Ultra light Performance Mass Spectrometer (Model- JMS-HX 11 OA).

\section{Results and discussion}

\subsection{Schiff Bases Characterization}

The tridentate Schiff base TPCA-ATPH (Lㅌ) was prepared by the condensation of 2-thiophenecarboxaldehyde (TPCA) and 2-aminothiophenol (ATP) in their 1:1 molar ratio. Another tetradentate Schiff base TPCA-pn-TPCA $\left(\mathrm{L}_{1}\right)$ was prepared by the condensation of 1,2-propanediamine (pn) with 2-thiophenecarboxaldehy (TPCA) in their 1:2 molar ratio. Both ligands were obtained after reflux and then on cooling as brownish precipitates. The Schiff bases were subjected to elemental analyses. The results of elemental analyses $(\mathrm{C}, \mathrm{H}, \mathrm{N})$ with molecular formulae and the melting points are presented in Table 1. The results obtained are in good agreement with those calculated for the suggested formulae and the melting points are sharp, indicating the purity of the prepared Schiff bases. The structure of these Schiff bases is also confirmed by mass, IR and ${ }^{1} \mathrm{H}$ NMR spectra. The mass spectrum of L $\underline{H}$ shows a well-defined parent peak at $\mathrm{m} / \mathrm{z}=218(\mathrm{M}+)$, with a relative intensity $=15 \%$. And that of $L_{1}$ shows a well-defined parent peak at $\mathrm{m} / \mathrm{z}=264$, with a relative intensity $=5 \%$. The parent ion and the fragments obtained 
by cleavage in different positions in the ligand molecules are shown in scheme 1 . In the ${ }^{1} \mathrm{H}-\mathrm{NMR}$ spectra of the ligands the formation of the Schiff base is supported by the presence of a singlet at $\delta 8.72$ and multiplet at $\delta 6.91 \mathrm{ppm}$, corresponding to the azomethine proton $(-\mathrm{CH}=\mathrm{N}-)$ and to the H-5 proton of the thiophen ring, respectively. Signals observed at $\delta 7.92-7.79 \mathrm{ppm}$ are due to three protons of aromatic ring. SH signal in the spectrum of the $\mathrm{L} \underline{\mathrm{H}}$ ligand appeared at $3.35 \mathrm{ppm}$. Aliphatic hydrogens of the ligand, TPCA-pn-TPCA $\left(\mathrm{L}_{1}\right)$ are appeared at 3.56, 3.43 and 1.29 ppm as doublet, multiplet and doublet, respectively. Characteristic $v(\mathrm{C}=\mathrm{N})$ stretching vibration is found in the free ligands at 1602 and $1633 \mathrm{~cm}^{-1}$ for the ( $\underline{\mathrm{H}}$ and $\left.\mathrm{L}_{1}\right)$ ligands.

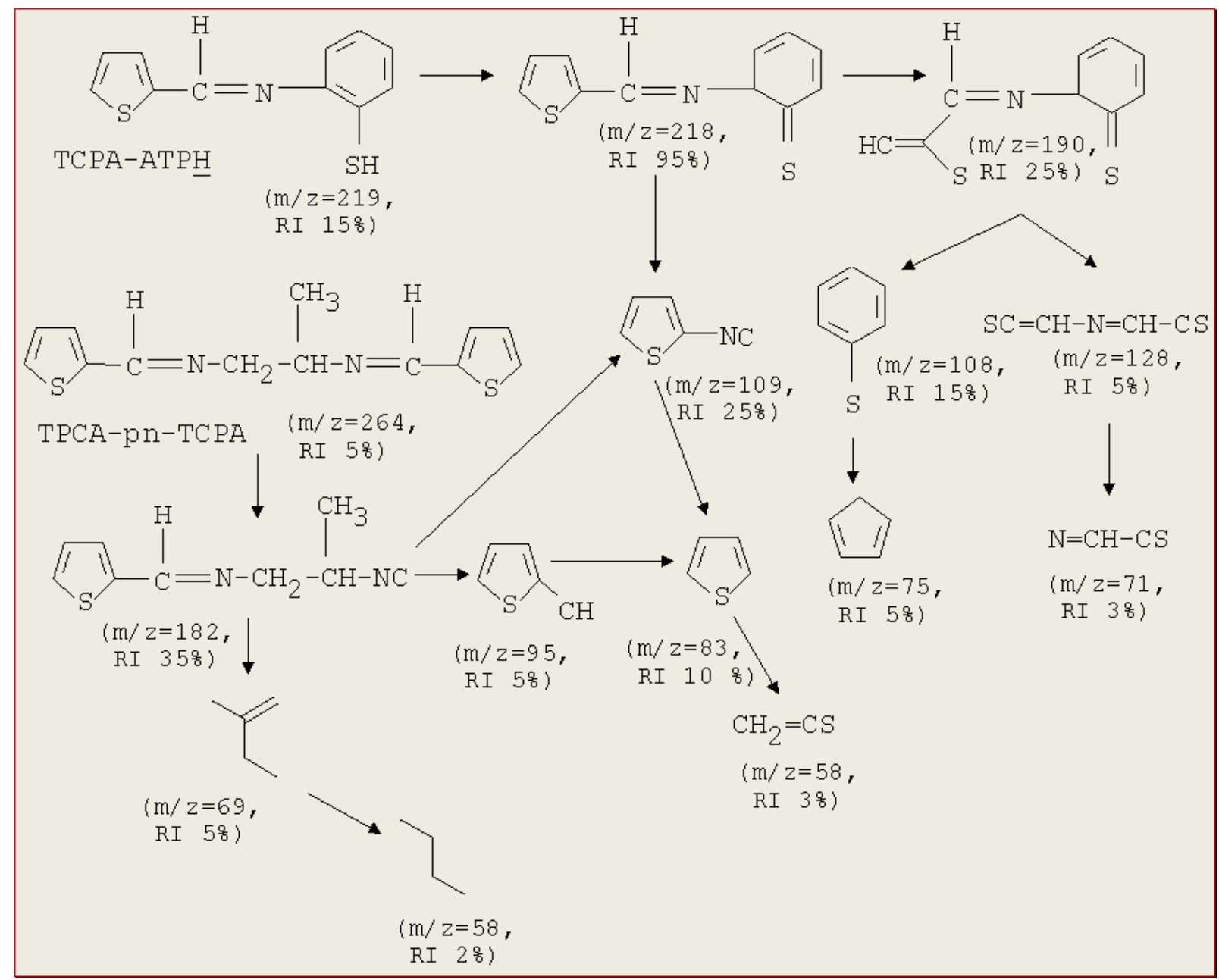

Scheme 1. The parent ion and the fragments obtained by cleavage in different positions in the ligand molecules

\subsection{Characterization of Complexes}

The complexes of the monobasic tridentate and neutral tetradentate Schiff bases were prepared by the reaction of respectively $1: 2$ and $1: 1$ molar ratio of metal cation (chloride salt of metals) and the Schiff base solutions in ethanolic medium. The ligand, TPCA-ATP $\underline{H}$ acted as uninegative tridentate anion on removal of the one proton from which $\left[\mathrm{M}(\mathrm{L})_{2}\right]$ type complexes were obtained. Whereas the ligand, [TPCA-pn-TPCA] acted as a neutral tetradentate one, from which $\left[\mathrm{M}\left(\mathrm{L}_{1}\right) \mathrm{Cl}_{2}\right]$ type complexes were obtained. Most of the complexes are insoluble in alcohol, ether, and acetone. Some of them are moderately soluble in chloroform and DMSO. But most of the complexes are highly soluble in DMF. From analysis it is observed that the values are in good agreement with those of calculated ones indicating the formation of the desired complexes with 1:2 (for TPCA-ATP $\underline{H}$ ) and 1:1 (other ligands) metal-ligand ratio. The representative diagram for the preparation of some Schif base ligands and its metal (M) complexes are given in scheme 2, 3 .

\subsubsection{Identification Test of CT Ions}

The presence of $\mathrm{Cl}^{-}$ions in the complexes was characterized by the qualitative procedure. Little amount of the prepared complex was taken in a test tube. Then concentrated nitric acid $\left(\mathrm{HNO}_{3}\right)$ was added to the sample and heated for the decomposition. Silver nitrate solution was added to this test solution and a white precipitates (silver chloride) was found, which was soluble in ammonia solution. This indicated the presence of the $\mathrm{Cl}^{-}$ion in the complex solution. 


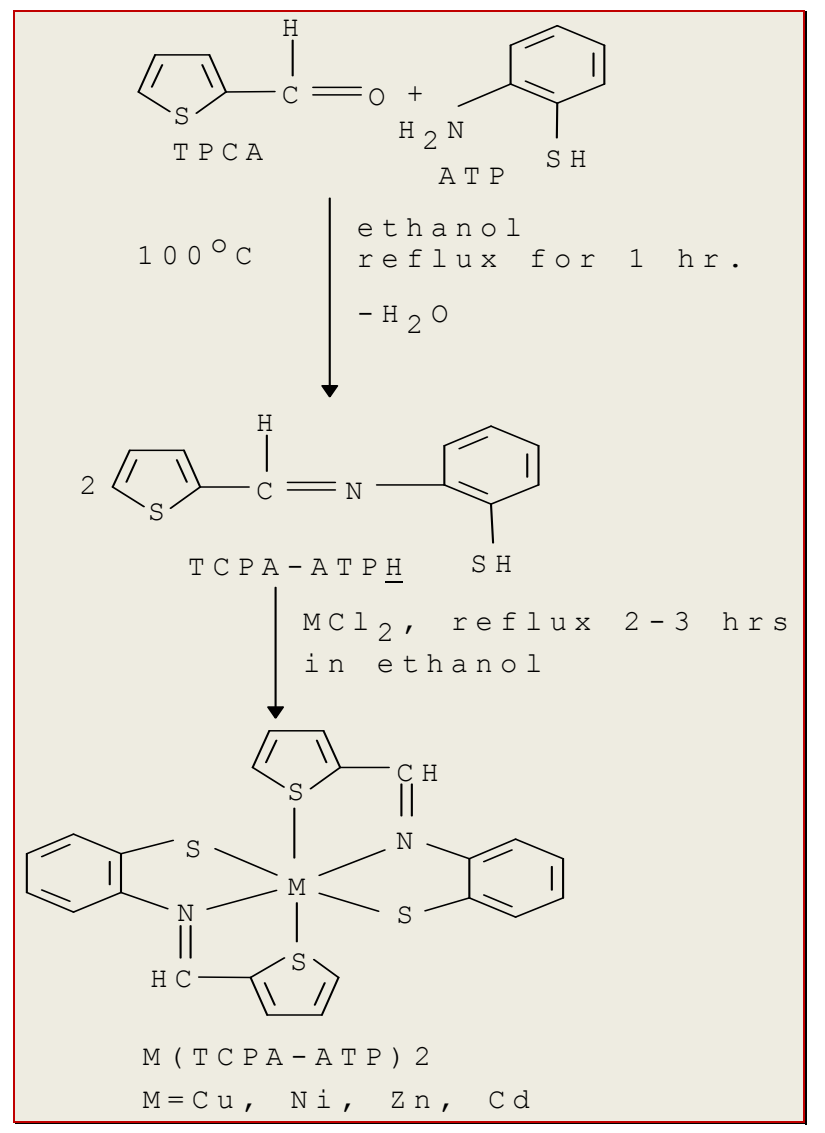

Scheme 2. The representative diagram for the preparation of some Schif base ligand, (TPCA-ATP $\underline{H}$ ) and its metal (M) complexes

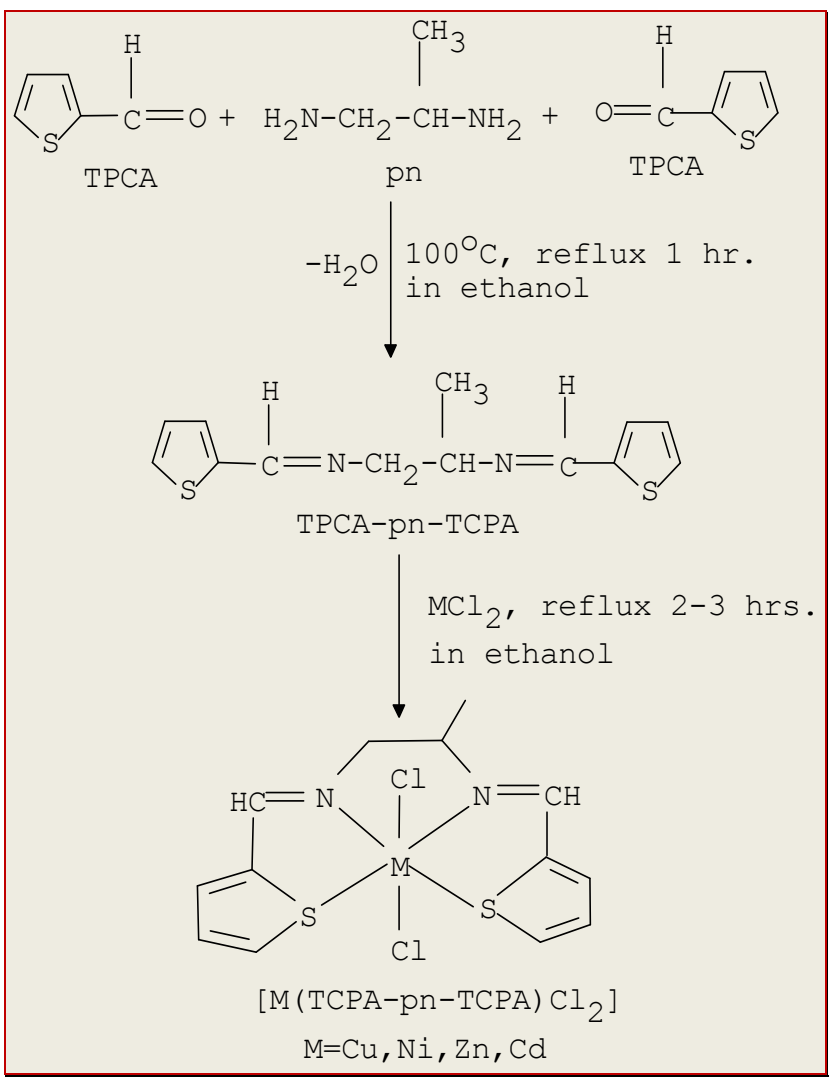

Scheme 3. The representative diagram for the preparation of some Schif base ligand, (TPCA-pn-TPCA) and its metal (M) complexes

\subsubsection{Elemental Analyses of the Complexes}

The results of elemental analyses, as shown in Table 1, are in good agreement with those required by the proposed formulae. The formation of these complexes may proceed according to the following equations given in scheme 2,3 .

\subsubsection{Infrared Spectra}

The infrared spectra for the present compounds taken in the range $400-4000 \mathrm{~cm}^{-1}$ help to indicate regions of absorption vibrations. The main stretching modes are for $v_{\mathrm{S}-\mathrm{H}}, v_{\mathrm{C}=\mathrm{N}}, v_{\mathrm{C}=\mathrm{C}}, v_{\mathrm{C}-\mathrm{N}}, v_{\mathrm{C}-\mathrm{S},} v_{\mathrm{M}-\mathrm{N}}$ and $v_{\mathrm{M}-\mathrm{S}}$. The IR data of the spectra of Schiff base ligands ( $\underline{L} \underline{H}$ and $L_{1}$ ) and their complexes are presented in Table 2 . The IR spectra of the complexes were compared with those of the free ligands in order to determine the coordination sites that may be involved in chelation. The position and/or the intensities of these peaks are expected to change upon chelation. The peak between 1620 and $1580 \mathrm{~cm}^{-1}$ have been assigned to $v_{\mathrm{C}=\mathrm{N}}$ band [8]. This band shows a downward shift by about $25-35 \mathrm{~cm}^{-1}$ in the spectra of all the metal complexes, indicating the participation of the azomethine nitrogen in coordination with metals $[5,8,9]$. Upon comparison, it was determined that the $v(\mathrm{C}=\mathrm{N})$ stretching vibration is found in the free ligands at 1604 and $1633 \mathrm{~cm}^{-1}$ for the $\mathrm{LH}$ and $\mathrm{L}_{1}$ ligands, respectively. This band was shifted to higher or lower wave numbers in the complexes, indicating the participation of the azomethine nitrogen in coordination (M-N) [10]. The bands appearing between 1520 and 1600 $\mathrm{cm}^{-1}$ have been assigned to aromatic or thiophene $v_{\mathrm{C}=\mathrm{C}}$. The shifted band in many cases is coincident with the $\mathrm{C}=\mathrm{C}$ band, which then shows greater intensity or broadening. The $v_{C=N}$ modes are often mixed with higher frequency $v_{\mathrm{C}=\mathrm{C}}$ (near $1600 \mathrm{~cm}^{-1}$ ) and are seen as a strong band [5,9]. The bands appearing at $1315-1400 \mathrm{~cm}^{-1}$ (specially the highest frequency ones near $1400 \mathrm{~cm}^{-1}$ ) have been assigned to $v_{\mathrm{C}-\mathrm{N}}$ mode $[8,9]$. It was observed that the symmetric vibrations of C-S, which appeared as a band near $701 \mathrm{~cm}^{-1}$ in the ligand spectrum, has been shifted to lower frequencies after complexation. Similarly a weak band of S-H, which appeared at $2650 \mathrm{~cm}^{-1}$ in the case of ligand, has been disappeared in the spectrum of all complexes [6]. However, the participation of the $\mathrm{SH}$ group in chelation is ascertained from the shift of the $v_{\text {asym(C-S })}$ and $v_{\text {sym(C-S }}$ from $706 \mathrm{~cm}^{-1}$ and $758 \mathrm{~cm}^{-1}$ to lower or higher wave numbers in the spectra of the complexes [14]. The sharp IR ligand bands at $824 \mathrm{~cm}^{-1}$ assigned as $v_{(\mathrm{C}-\mathrm{S}-\mathrm{C})}$ of thiophene moiety, for the ligand, shifted to $827-828 \mathrm{~cm}^{-1}$ for metal complexes [3]. The $v_{(\mathrm{M}-\mathrm{S})}$ bands appeared at 467-468 (thiophene) and 428-431 $\mathrm{cm}^{-1}$ (thiophenol) for metal complexes [6]. Spinu and Kriza [12] have prepared Schiff base complexes who observed the bands at $563-567 \mathrm{~cm}^{-1}$ in have been assigned to $v_{(\mathrm{M}-\mathrm{N})}$ mode and the $v_{(\mathrm{M}-\mathrm{S})}$ bands appeared at $428-431 \mathrm{~cm}^{-1}$ for the complexes. New bands at 507-619 $\mathrm{cm}^{-1}$ in $\mathrm{L} \underline{\mathrm{H}}$ and $\mathrm{L}_{1}$ metal complexes, have been assigned to $v(\mathrm{M}-\mathrm{N})$ mode. The $v(\mathrm{M}-\mathrm{S})$ bands appeared at $420-430 \mathrm{~cm}^{-1}$ (thiophene) and 440-469 $\mathrm{cm}^{-1}$ (thiophenol) for $\mathrm{L} \underline{\mathrm{H}}$ metal complexes $[6,12]$. Therefore, from the IR spectra, it is 
concluded that the L $\underline{H}$ ligand behaves as a uninegtively tridentate ligand coordinated to the metal ions via deprotonated thiophenol S, azomethine $\mathrm{N}$, and thiophene $\mathrm{S}$; whereas $\mathrm{L}_{1}$ behaves as a neutral tetradentate ligand coordinated to the metal ions via azomethine $\mathrm{N}$ and thiophene S.

Table 2. Infrared spectral bands of Schiff bases and their metal complexes

\begin{tabular}{|c|c|c|c|c|c|c|c|c|c|}
\hline Complexes & $\boldsymbol{v}_{\mathbf{C}=\mathbf{N}}$ & $\boldsymbol{v}_{\mathrm{C}=\mathrm{C}}$ & $\boldsymbol{v}_{\mathrm{C}-\mathrm{N}}$ & $v_{\text {C-S-C }}$ & $\begin{array}{c}\boldsymbol{v}_{\mathrm{C}-\mathrm{s}} \\
\text { (sym) }\end{array}$ & $\begin{array}{c}\boldsymbol{v}_{\mathrm{C}-\mathrm{s}} \\
\text { (asym) }\end{array}$ & $\mathbf{v}_{\mathrm{M}-\mathrm{N}}$ & $\begin{array}{l}v_{M-S} \\
(-\mathrm{ol}) \\
\end{array}$ & $\begin{array}{l}v(\mathrm{M}-\mathrm{S}) \\
\text { (-phene) }\end{array}$ \\
\hline TPCA-АТРН & $1604(s)$ & $1550 \mathrm{~m}$ & 1425(sh) & 893(vs) & & & & & \\
\hline $\mathrm{Ni}(\mathrm{TPCA}-\mathrm{ATP})_{2}$ & $\begin{array}{l}1635(\mathrm{~m}) \\
1645(\mathrm{~m})\end{array}$ & $1581 \mathrm{~m}$ & $\begin{array}{l}1386(\mathrm{w}) \\
1338(\mathrm{~m})\end{array}$ & $802(s)$ & $755 \mathrm{~s}$ & $710 w$ & $\begin{array}{l}617(\mathrm{~m}) \\
507(\mathrm{w})\end{array}$ & $469 \mathrm{~m}$ & $430 \mathrm{~m}$ \\
\hline $\mathrm{Cu}(\mathrm{TPCA}-\mathrm{ATP})_{2}$ & $\begin{array}{c}1680(\mathrm{w}) \\
1640(\mathrm{~ms})\end{array}$ & $1562 \mathrm{~m}$ & $\begin{array}{c}1435(\mathrm{~ms}) \\
1420 \mathrm{~ms})\end{array}$ & 859(vs) & $750 \mathrm{~s}$ & $705 \mathrm{~s}$ & $579(w)$ & $440(w)$ & $422(w)$ \\
\hline $\mathrm{Zn}(\mathrm{TPCA}-\mathrm{ATP})_{2}$ & $\begin{array}{c}1625(\mathrm{~m}) \\
1616(\mathrm{~ms})\end{array}$ & $1575 \mathrm{~s}$ & $\begin{array}{l}1458(\mathrm{~ms}) \\
1388(\mathrm{~ms})\end{array}$ & $813(\mathrm{~s})$ & $760 \mathrm{~m}$ & $715 \mathrm{~s}$ & $615(s)$ & $468 \mathrm{~m}$ & $430 \mathrm{~m}$ \\
\hline $\mathrm{Cd}(\mathrm{TPCA}-\mathrm{ATP})_{2}$ & $1635(\mathrm{~ms})$ & $1562 \mathrm{~m}$ & $1436(v s)$ & $859(\mathrm{~s})$ & $758 \mathrm{~m}$ & $709 \mathrm{~m}$ & $472(w)$ & $456 \mathrm{~m}$ & $420(w)$ \\
\hline TPCA-pn-TPCAH ${ }_{2}$ & 1633(vs) & $1550 \mathrm{~ms}$ & $1425(\mathrm{sh})$ & 898(vs) & & & & & \\
\hline [Ni(TPCA-pn-TPCA)Cl $\left.{ }_{2}\right]$ & $\begin{array}{l}1650(\mathrm{~m}) \\
1640(\mathrm{~m})\end{array}$ & $1577 \mathrm{~s}$ & $\begin{array}{c}1388(\mathrm{~s}) \\
1338(\mathrm{~m})\end{array}$ & $827 \mathrm{sh}$ & $763 \mathrm{~m}$ & $725 \mathrm{~s}$ & $509(\mathrm{~m})$ & & $428 \mathrm{~m}$ \\
\hline$\left[\mathrm{Cu}(\mathrm{TPCA}-\mathrm{pn}-\mathrm{TPCA}) \mathrm{Cl}_{2}\right]$ & $\begin{array}{c}1635(\mathrm{vs}) \\
1613(\mathrm{~s})\end{array}$ & $1568 \mathrm{~m}$ & $1388(\mathrm{~ms})$ & $828 \mathrm{sh}$ & $753 \mathrm{~s}$ & $705 \mathrm{~s}$ & $615(s)$ & & $429 \mathrm{~m}$ \\
\hline [Zn(TPCA-pn-TPCA)Cl $\left.{ }_{2}\right]$ & 1635 (vs) & $1581 \mathrm{~s}$ & $1338(\mathrm{~ms})$ & $831(\mathrm{~s})$ & $745 s$ & $712 w$ & $649(s)$ & & $431 \mathrm{~m}$ \\
\hline [Cd(TPCA-pn-TPCA)Cl $\left.{ }_{2}\right]$ & $1635(w)$ & $1581 \mathrm{~s}$ & $1388(\mathrm{~m})$ & $827(\mathrm{~m})$ & $758 \mathrm{~m}$ & $709 \mathrm{~m}$ & $617(\mathrm{~ms})$ & & $430 \mathrm{~m}$ \\
\hline
\end{tabular}

\subsection{4. ${ }^{1}$ H NMR Spectra}

The ${ }^{1} \mathrm{H}$ NMR spectra of the free ligands and their diamagnetic $\mathrm{Zn}(\mathrm{II})$ complex shows that the $\mathrm{SH}$ signal appeared in the spectrum of the LH ligand at $3.36 \mathrm{ppm}$ and completely disappeared in the spectrum of its $\mathrm{Zn}$ (II) complex, indicating that the $\mathrm{SH}$ proton is removed by chelation with the $\mathrm{Zn}$ (II) ion. The peaks at 8.71 and 7.09 ppm characteristic to the azomethine and thiophene protons are down fielded to 8.30 and $6.87 \mathrm{ppm}$ respectively in the complexes supporting well binding of the azomethine groups of ligand to metal ions. The signals for aromatic hydrogens at 7.91-7.79 $\mathrm{ppm}$ are down fielded to 7.52-7.39 ppm.

\subsubsection{Electronic Spectra}

The absorption spectra for $2.5 \times 10^{-3} \mathrm{M}$ solution of $\mathrm{L} \underline{\mathrm{H}}$ and $\mathrm{L}_{1}$ ligands in absolute ethanol ranging from 200 to 700 $\mathrm{nm}$ against the same solvent as a blank. L $\underline{H}$ gives 3 sharp bands at 216, 278 and $337 \mathrm{~nm}$ and $\mathrm{L}_{1}$ shows 3 bands at 253, 316 and $402 \mathrm{~nm}$. These bands can be attributed to $\pi-\pi *$ and $\mathrm{n}-\pi *$ transitions within the Schiff bases. Being a $\mathrm{d}^{10}$ system, the present $\mathrm{Cd}(\mathrm{II})$ and $\mathrm{Zn}(\mathrm{II})$ complexes show no $\mathrm{d}-\mathrm{d}$ transition in the visible region, and are colored only through their intense charge transfer absorptions tailing in from the ultraviolet. Besides, the other bands are due to intra ligand transitions. The present $\mathrm{Ni}(\mathrm{II})$ complexes show spectral bands around 400-550 nm which may be attributed to the $d-d$ transition. The high energy peaks are tentatively assumed as due to $\pi \rightarrow \pi^{*}, n \rightarrow \pi^{*}$ and $n \rightarrow \sigma^{*}$ transitions. Electronic spectra of the $\mathrm{Cu}$ (II) complex displayed bands at 286-563 $417 \mathrm{~nm}$ which may be assigned to $\pi \rightarrow \pi^{*}$ transition of thiophene ring, $\mathrm{L} \rightarrow \mathrm{Cu}$ charge transfer, $\mathrm{n}-\pi^{*}$ transition of azomethine group and d-d transitions.

\subsubsection{Magnetic Measurement}

From the experimental values of magnetic measurements of the prepared complexes, it is revealed that $\mathrm{Cd}$ (II) and $\mathrm{Zn}$ (II) complexes of the Schiff bases are diamagnetic, thus indicating the $\mathrm{d}^{10}$ electronic configuration of $\mathrm{Cd}(\mathrm{II})$ and $\mathrm{Zn}(\mathrm{II})$. The $\mathrm{Ni}(\mathrm{II})$ complexes reported herein are high-spin with room temperature magnetic moment values of 3.69-4.12 B.M., which are in the normal range observed for octahedral $\mathrm{Ni}(\mathrm{II})$ complexes ( $\mu$ eff $=2.9-3.3 \mathrm{~B}$.M). The $\mathrm{Cu}$ (II) complex was found to be paramagnetic as expected for $d^{9}$ configuration. The magnetic moment value is $1.71-1.72 \mathrm{BM}$ is very close to the spin only value 1.73 , which support that a octahedral geometry of $\mathrm{Cu}$ (II) complex is most likely.

\subsubsection{Conductance Measurement}

The chelates were dissolved in DMF and the molar conductivities of $10^{-3} \mathrm{M}$ of their solutions at $25 \pm 2{ }^{\circ} \mathrm{C}$ were measured. The molar conductivity values of the metal chelates of $\mathrm{LH}$ and $\mathrm{L}_{1}$ ligands $\left(\Lambda m=10-29 \Omega^{-1} \mathrm{~mol}^{-1} \mathrm{~cm}^{2}\right)$ indicate that these complexes are non-electrolytes. Based on these data, it is clear that chelates are considered as 1:2 $\left[\mathrm{M}(\mathrm{L})_{2}\right]$, indicating the nonionic nature of the bonding of the complex nucleus. The +2 oxidation states of $\mathrm{M}$ (II) is satisfied by two uni-negtively charged tridentate (TPCA-ATP $\underline{H}$ ) ligands as expected. Since the Schiff base ligand (TPCA-pn-TPCA) contains no charge, so +2 oxidation states of $\mathrm{M}$ (II) are satisfied by two negatively charged monodentate $\mathrm{Cl}^{-}$ligands in the complexes of $\left[\mathrm{M}\left(\mathrm{L}_{1}\right) \mathrm{Cl}_{2}\right]$ residing in coordination sphere.

Table 3 shows the electronic spectral data, magnetic moments and molar conductivity for the prepared complexes. 
Table 3. The electronic spectra, magnetic moments and conductivity data for the prepared complexes

\begin{tabular}{|c|c|c|c|c|c|}
\hline No. & Complexes & Medium & Spectral bands (nm) & $\begin{array}{l}\mu \text { eff } \\
\text { (B.M) }\end{array}$ & $\begin{array}{l}\lambda_{\mathrm{m}}^{\mathrm{o}} \\
\mathrm{ohm}^{-1} \mathrm{~cm}^{2} \mathrm{~mol}^{-1}\end{array}$ \\
\hline & TPCA-АТPH & & $337,278,216$ & & \\
\hline 1 & [Ni(TPCA-ATP)] & & $550,453,426$ & 4.12 (para) & 23 \\
\hline 2 & {$\left[\mathrm{Cu}(\mathrm{TPCA}-\mathrm{ATP})_{2}\right]$} & & $563,433,388$ & 1.71 (para) & 21 \\
\hline 3 & [Zn(TPCA-ATP)] & & $353,318,286$ & 0.47 (Dia.) & 29 \\
\hline \multirow[t]{2}{*}{4} & {$\left[\mathrm{Cd}(\mathrm{TPCA}-\mathrm{ATP})_{2}\right]$} & DMF & $333,281,273$ & 0.68 (Dia.) & 15 \\
\hline & TPCA-pn-TPCA & & $402,316,263$ & & \\
\hline 5 & [Ni(TPCA-pn-TPCA)Cl $\left.{ }_{2}\right]$ & & $540,438,352$ & 3.69 (para) & 15 \\
\hline 6 & [Cu(TPCA-pn-TPCA)Cl $\left.{ }_{2}\right]$ & & $560,322,286$ & 1.72 (para) & 14 \\
\hline 7 & [Zn(TPCA-pn-TPCA) $\left.\mathrm{Cl}_{2}\right]$ & & 281,273 & 0.51 (Dia.) & 10 \\
\hline 8 & [Cd(TPCA-pn-TPCA)Cl $\left.{ }_{2}\right]$ & & 317,271 & 0.55 (Dia.) & 10 \\
\hline
\end{tabular}

\subsection{Structural Interpretation}

The structures of the complexes of Schiff bases $\mathrm{L} \underline{\mathrm{H}}$ and $\mathrm{L}_{1}$, with $\mathrm{Ni}(\mathrm{II}), \mathrm{Cu}(\mathrm{II}), \mathrm{Zn}(\mathrm{II})$, and $\mathrm{Cd}(\mathrm{II})$ ions were confirmed by elemental analyses, UV-Vis, mass, IR, ${ }^{1} \mathrm{H}$ NMR, molar conductance and magnetic analysis data. Therefore, from the IR spectra, it is concluded that $\mathrm{LH}$ behaves as a uni-negatively tridentate ligand, coordinated to the metal ions via azomethine $\mathrm{N}$, thiophene $\mathrm{S}$ and deprotonated thiophenol S. $\mathrm{L}_{1}$ behaves as a neutral terdentate ligand, coordinated to the metal ions via azomethine $\mathrm{N}$, and thiophene $\mathrm{S}$. From the molar conductance data, it was found that the M(II) chelates are considered as 2:1 (L:M) composition with L ligand. While complexes with the $\mathrm{L}_{1}$ ligand are considered as $1: 1$ composition. Non-electrolytic nature is satisfied by two negatively charged monodentate $\mathrm{Cl}^{-}$ligands. After coordination, all signals in ${ }^{1} \mathrm{H}$ NMR spectra are down fielded. On the basis of the above observations and from the magnetic measurements, octahedral geometries are suggested for the investigated complexes with the formulae, $\left[\mathrm{M}(\mathrm{L})_{2}\right]$ and $\left[\mathrm{M}\left(\mathrm{L}_{1}\right) \mathrm{Cl}_{2}\right]$.

\subsection{Stability Constants}

The stability constants of the $\mathrm{Ni}(\mathrm{II}), \mathrm{Cu}(\mathrm{II}), \mathrm{Zn}(\mathrm{II})$ and $\mathrm{Cd}$ (II) complexes with HL are determined potentiometriclly using the method described by Bjerrum [15]. The complex-forming abilities of the metal ions are frequently characterized by stability orders. The order of stability constants was found to be $\mathrm{Cd}^{2+}<\mathrm{Ni}^{2+}<\mathrm{Cu}^{2+}>\mathrm{Zn}^{2+}$ for divalent metal ions. The stability of $\mathrm{Cu}(\mathrm{II})$ complex is considerably more as compared to other metals ions. Under the influence of the ligand field, $\mathrm{Cu}(\mathrm{II})\left(3 \mathrm{~d}^{9}\right)$ will receive some extra stabilization due to tetragonal distortion of the octahedral symmetry in its complexes. The $\mathrm{Cu}(\mathrm{II})$ complex will be further stabilized due to the Jahn-Tellar effect.

\subsection{Effect of Chemicals on the Bacterial Growth}

In the present work, Nickel(II), Copper(II), Zinc(II) and
Cadmium(II) complexes were selected for antibacterial activity against four human pathogenic bacteria. Antibacterial activity of complexes was studied on one Gram positive and three Gram-negative bacteria by disc diffusion method. The selected bacteria can cause different fatal diseases; viz. Salmonella typhe causes typhoid, each of Escherichia coli and Bacillus cerelus cause gastroenteritis. The inhibition zones of the test organisms for different complexes are represented in Figure 1. The results are graphically shown in Figures 2, 3 and for the complexes of the respective ligand. Both ligands themselves are found to be moderately effective against tested bacteria. Most cases chelation increases their antibacterial activity than free ligands. Nickel(II) complexes of $\underline{L} \underline{H}$ are effective against the Gram-positive and Gram-negative bacteria except Eschericahia coli whereas that of $\mathrm{L}_{1}$ are effective for both Eschericahia coli and pseudomonas alruginosa. Copper(II) complexes of ligand $\mathrm{L} \underline{\mathrm{H}}$ exhibit effective antibacterial activity against all bacteria except Bacillus cereu whereas that of $\mathrm{L}_{1}$ are quite ineffective to almost all bacteria. Zinc(II) complexes of ligand $\mathrm{L} \underline{\mathrm{H}}$ are moderately effective to all bacteria except Bacillus cereu whereas that of $\mathrm{L}_{1}$ are more effective for both Eschericahia coli and pseudomonas alruginosa. All the cadmium(II) complexes are quite effective against the Eschericahia coli and Salmonella typhi and ineffective against pseudomonas alruginosa. The higher inhibition zone of metal complexes than those of the ligands can be explained on the basis of overtone's concept and Chelation theory. On chelation, the polarity of the metal ion will be reduced to greater extent due to the overlap of the ligand orbital and partial sharing of the positive charge of the metal ions with donor groups. Further, it increases the delocalization of $\pi$-electrons over the whole chelation ring and enhances the penetration of the complexes into lipid membranes and blocking o the metal bonding sites in the enzymes of microorganisms. There are other factors which also increases the activity are solubility, conductivity and bond length between the metal and ligand. 

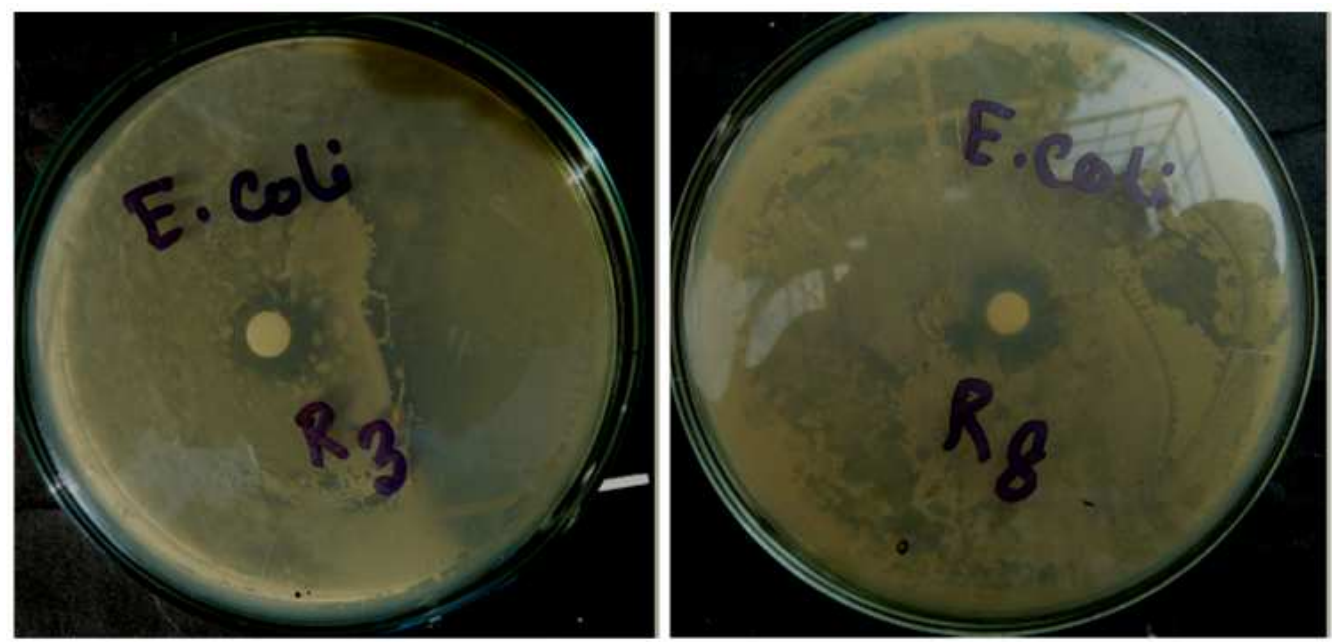

Fig. 1. Inhibition zone against Escherichia coli by the complexes $R_{3^{-}}\left[\mathrm{Zn}(T P C A-A T P)_{2}\right]$ and $R_{8^{-}}\left[C d(T P C A-p n-T P C A) C l_{2}\right]$.

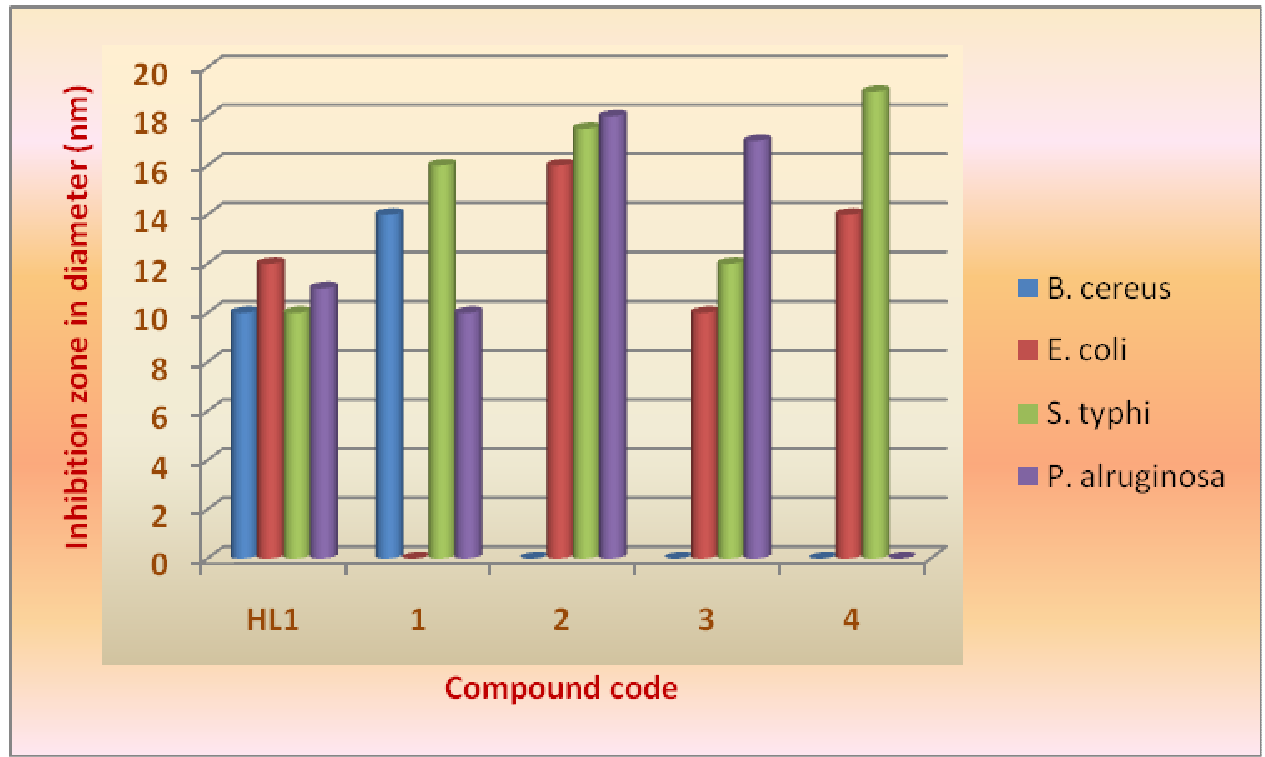

Fig. 2. The graphical presentation of the antibacterial activity against tested bacteria by the complexes of ligand, TPCA-ATP (HL).

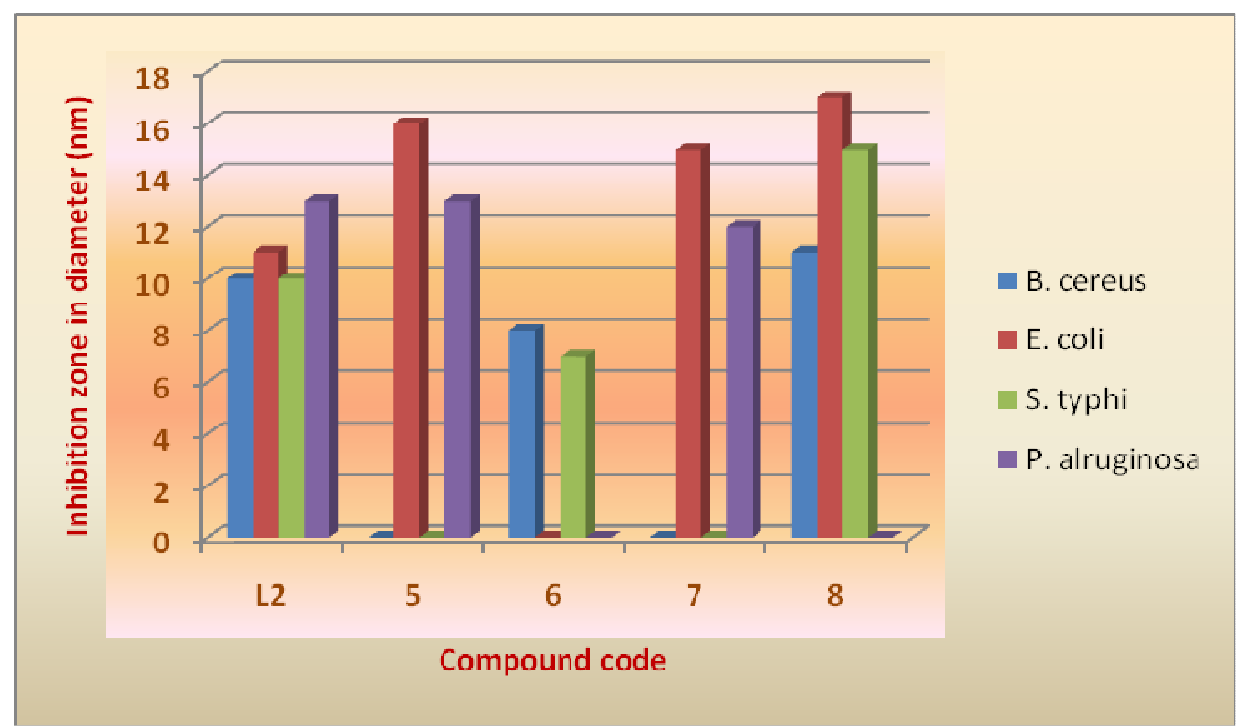

Fig. 3. The graphical presentation of the antibacterial activity against tested bacteria by the complexes of ligand, TPCA-pn-TPCA $\left(L_{l}\right)$. 


\section{Conclusion}

The new Schiff bases were derived by the condensation of 2-thiophenecarboxaldehyde with 2-aminothiophenol (L프) and propane-1,2-diamine $\left(\mathrm{L}_{1}\right)$. The complexes of the types $\left[\mathrm{M}(\mathrm{L})_{2}\right]$ with tridentate Schiff base $(\mathrm{LH})$ ligand and $\left[\mathrm{M}\left(\mathrm{L}_{1}\right) \mathrm{Cl}_{2}\right]$ with tetradentate Schiff base ligand $\left(\mathrm{L}_{1}\right)$ were prepared $[\mathrm{M}=\mathrm{Ni}(\mathrm{II}), \mathrm{Cu}(\mathrm{II}), \mathrm{Zn}(\mathrm{II})$ and $\mathrm{Cd}(\mathrm{II})]$. The analytical data confirmed the metal : ligand stoichiometry of the complexes. Conductivity measurements indicate their non-electrolytic nature. The magnetic measurements along with electronic spectral data of the prepared complexes support the electronic configuration of the central metal ion consistent with the +2 oxidation states of $\mathrm{Ni}(\mathrm{II}), \mathrm{Cu}(\mathrm{II}), \mathrm{Zn}(\mathrm{II})$ and $\mathrm{Cd}(\mathrm{II})$ ions. The synthesized metal complexes, in comparison to the uncomplexed Schiff base ligand, were screened for their antibacterial activity against pathogenic bacteria species. The activity of the some Schiff base complexes became more pronounced when coordinated with the metal ions.

\section{Acknowledgement}

Authors are pleased to acknowledge the Department of Microbiology, University of Chittagong, Bangladesh for cordial cooperation in collecting bacterial strains and performing antibacterial tests.

\section{References}

[1] M Vikotora; K Rudolfa; L Molbank. M354 Open Access Publication, 2004.
[2] A Ahmed; MA El-Sherif; T Eldebss. Spectrochimica Acta Part A, 2011, 79, 1803-1814.

[3] N Sari; P Gürkan. Z. Naturforsch. 2004, 59b, 692 - 698.

[4] K Jamuna; BR Naik; B Sreenu; K Seshaiah. J. Chem. Pharm. Res., 2012, 4(9), 4275-4282.

[5] M Montazerozohori; M Sedighipoor; S Joohari. Int. J. Electrochem. Sci., 2012, 7, 77-88.

[6] DA Chowdhury; MN Uddin; F Hoque. Chiang Mai J. Sci. 2010, 37(3), 443-450.

[7] DA Chowdhury; MN Uddin; MAH Sarker; Chiang Mai J. Sci. 2008, 35(3), 483-494.

[8] DA Chowdhury; MN Uddin; GK Chowdhury. The Chitt. Uni. J. of Sci. 2006, 30(1), 85-88.

[9] MN Uddin; DA Chowdhury; K Hossain, J. Chinese Chem. Soc., 2012, 59(12), 1520-1527.

[10] C S $\square$ Inu; M Pleniceanu; C Tigae. Turk J Chem, 2008, 32, 487-493.

[11] OB Ibrahim; MA Mohamed; MS Refat. Int. J. of Innovative Res. in Sci., Eng. and Tech. 2013, 2(11), 6355-6570.

[12] C Spinu; A Kriza; Acta Chim. Slov. 2000, 47, 179-185.

[13] MN Uddin; DA Chowdhury; MT Islam; F Hoque. Orbital Elec. J. Chem. 2012, 4(4), 273-287.

[14] AP Mishra; A Tiwari; R Jain. Int. J. Res. Pharm. Sci. 2011, 3(2), 186-191.

[15] J Bjerrum. "Metal Amine Formation in Aqueous Solution, Haase, Copenhagen, 1941. 